\title{
Uma pedra de esperanç: a fé profética, o liberalismo e a morte das leis Jim Crow*
}

\author{
David Chappell**
}

Enquanto muitos liberais acreditavam que educação e desenvolvimento econômico iriam corroer o preconceito racial, os líderes negros do movimento pelos direitos civis acreditavam - como os antigos Profetas Hebreus - que a tendência natural da sociedade era a corrupção. A inspiração profética ajudou os líderes negros a gerar solidariedade inédita e espírito de auto-sacrifício entre as massas negras do sul, cujo movimento assemelhou-se a um reavivamento religioso - com muito maior determinação que a demonstrada tanto por seus aliados liberais do norte, quanto por seus inimigos do sul.

Palavras-chave: Martin Luther King - Direitos Civis - Liberalismo

A stone of hope: prophetic faith, liberalism, and the death of Jim Crow While most liberals believed that education and economic development would wear down racial prejudice, black civil rights leaders believed - like the ancient hebrew prophets - that the natural tendency of society was towards corruption. Prophetic inspiration helped black leaders generate unprecedented solidarity and self-sacrifice among black southern masses, whose movement resembled a religious revival - with far more determination than either their northern liberal allies or their white southern enemies.

Keywords: Martin Luther King - Civil Rights - Liberalism

\footnotetext{
* Artigo recebido em março de 2008 e aprovado para publicação em maio de 2008.

** Professor do Departamento de História da University of Oklahoma.
} 


\section{Une pierre d'espoir : la foi prophétique, le libéralisme et la mort des lois Jim Crow}

Tandis que beaucoup de libéraux s'imaginaient que l'éducation et le développement économique allaient corroder le préjugé racial, les leaders noirs du mouvement pour les droits civils considéraient - à l'instar des anciens prophètes hébreux - que la tendance naturelle de la société était la corruption. Cette inspiration prophétique a aidé les leaders noirs à engendrer chez les masses noires du Sud, dont le mouvement ressemblait à un réavivement religieux, des sentiments de solidarité inédits et un esprit d'auto-sacrifice, de façon bien plus déterminée que leurs alliés libéraux du Nord et leurs ennemis du Sud.

Mots-clés: Martin Luther King - Droits Civil - Libéralisme

Este título foi extraído do discurso de Martin Luther King no Memorial Lincoln, proferido em 1963, e conhecido por suas palavras mais famosas: "Eu tenho um sonho". ${ }^{1}$

Naquela ocasião, poucos tinham esperança de que o importante projeto de lei de direitos civis, sendo debatido no Congresso naquele ano, pudesse ser aprovado. Era o primeiro projeto de lei sério e agressivo sobre direitos civis desde a Reconstrução. Mesmo os principais assessores do presidente John Kennedy, que haviam recentemente decidido apoiar inteiramente a lei, não tinham esperanças de que ela passasse. Mas King afirmava que ele ia de volta para o Sul com esperança de que seu povo seria capaz de retirar "uma pedra de esperança de uma montanha de desespero". ${ }^{2}$

Tal imagem - traduzida de forma mais ou menos livre do hebraico bíblico ebenezer - resume bem a filosofia do movimento de direitos civis. Comumente

\footnotetext{
${ }^{1}$ King notou que muitos iam ouvi-lo "saindo de desafios e sofrimentos excessivos (...) recémsaídos das celas apertadas das prisões (...) [e] de áreas onde a luta pela liberdade os deixara caídos pelas surras das tempestades da perseguição e cambaleantes dos ventos da brutalidade da polícia. Vocês se tornaram veteranos do sofrimento criativo. Continuem a trabalhar com a fé de que o sofrimento não merecido é redentor (...) Não se afundem no vale do desespero". Então, fazendo eco à Revelação de São João, o Divino, afirmou que ele sonhara que um dia, na Geórgia, os filhos dos antigos escravos e os donos dos escravos se sentariam juntos na mesa da fraternidade, na mesma medida em que "todos os vales serão louvados, todo morro e colina serão rebaixados, os lugares acidentados serão nivelados, e os lugares tortos serão feitos retos e a glória do Senhor será revelada e toda a carne a verá junta".

${ }^{2}$ No seu discurso, pontuado por metáforas bíblicas, King utilizou o verbo "to hew" para referir-se à retirada, extração de fragmentos de uma rocha através de entalhamento. A pedra é extraída da montanha num ato transformativo. Essa metáfora é crucial para o ponto que o autor estabelece no final do artigo. (N. do T.)
} 
traduzida por "pedra da esperança", ebenezer era o nome de muitas igrejas afroamericanas, incluindo a igreja de Martin Luther King Sr. em Atlanta. A fé que levou milhares de manifestantes negros do sul a vitórias incomuns em meados dos anos 1960 surgiu a partir de um entendimento realista das possibilidades de justiça social neste mundo. King e outros seis líderes importantes dos direitos civis entenderam que geralmente essas possibilidades eram mínimas. $\mathrm{O}$ desespero equivalia à montanha. A esperança era, em comparação, difícil de achar. Como uma canção de liberdade da época dizia: "A liberdade não é de graça: você tem de pagar um preço, você tem de se sacrificar, por sua liberdade”. King afirmou, em outro sermão em 1963, que as crianças negras presas em Birmingham estavam cavando um "túnel de esperança" na montanha de desespero. Esta filosofia - esta visão decididamente negativa da natureza humana e da história - emergiu como um tema dominante do movimento. ${ }^{3}$

Três descobertas, exemplificadas adiante, contribuíram para uma nova interpretação do movimento de direitos civis, que percebe um profundo ceticismo na natureza humana como central na estratégia do movimento. Infelizmente, os historiadores não têm levado em conta esse ceticismo, talvez porque ele contradiga a fé histórica do liberalismo na humanidade. (A versão dominante da fé liberal se centra em uma humanidade imaginária do futuro, na qual a descoberta científica, a educação de massa e o crescimento econômico erradicam a tradição. Uma crença variante dominou a profissão de historiadores desde os anos 1970: a fé no povo de raízes "comuns" que irá triunfar, se os acadêmicos que pensam corretamente os ajudarem a encontrar sua voz.) Quase todas as histórias sobre os direitos civis viram o movimento de direitos civis como algo de espírito liberal, e sua oposição como uma defesa conservadora típica do status quo.

Mas os líderes negros sulistas do movimento rejeitaram as pressuposições liberais fundamentais, e seus inimigos segregacionistas falharam em se comportarem como conservadores tradicionais. Enquanto isso, os liberais não lograram êxito em seus esforços para confrontar o racismo - até que se viram arrastados pelo movimento negro do sul, que mais parecia uma tent revival ${ }^{4}$ do que um encontro da ACLU (American Civil Liberties Union - União

\footnotetext{
${ }^{3}$ Este artigo se baseia muito em meu livro, A stone of hope: prophetic religion and the death of Jim Crow, no prelo, 2003. Copyright c2003 da University of North Carolina Press, http:// www.uncpress.unc.edu.

${ }^{4}$ Um tent revival é uma forma tradicional e popular de pregação evangélica no sul dos Estados Unidos, que se vale de uma instalação provisória. (N. do T.)
} 
Americana dos Direitos Civis). Quando o revival acabou, os liberais tinham fracassado outra vez.

\section{Inveja liberal do púlpito}

Os sucessos políticos do movimento negro do sul dependiam de uma aliança com os liberais. No entanto, a fé que animava os liberais americanos da segunda metade do século XX diferia radicalmente daquela dos líderes dos direitos civis. Os liberais tinham fé no poder da razão humana para vencer o "preconceito" e outros vestígios de um passado supersticioso e não-iluminado (os liberais concederam sentido depreciativo ao termo "preconceito", associando-o exclusivamente à resistência irracional à verdade, e não a valores ou princípios incorruptíveis). Os liberais acreditavam que o progresso estava a caminho: mais educação, bem como desenvolvimento econômico, levaria os povos atrasados, incluindo os sulistas brancos, a abandonar suas tradições irracionais. Assim, os liberais, embora sinceros em sua devoção à liberdade e à igualdade dos negros, não viam razão para fazerem nada drástico para promoverem a liberdade e a igualdade dos negros: esses avanços viriam naturalmente, aos poucos. ${ }^{5}$ Forçá-los poderia retardar esse avanço, provocando uma reação dos sulistas não-iluminados e potencialmente perigosos. $\mathrm{O}$ interessante - e o que nenhum pesquisador tem abordado até agora - é que os pensadores liberais mais articulados e sensíveis estavam há muito cientes da fraqueza cultural e política de sua fé na racionalidade.

As elucubrações desses pensadores articulados e sensíveis dão-nos uma visão do âmago do liberalismo americano. Elas nos dizem muito sobre a inabilidade do liberalismo em alcançar seus próprios objetivos de liberdade e igualdade e começam a sugerir por que um movimento de direitos civis, vindo de fora do liberalismo, era necessário. Por trás do pensamento liberal americano dos meados do século XX estavam figuras tais como John Stuart Mill e William James. Suas biografias tinham em comum a experiência de um colapso mental, que os levara a questionar o controle racional da natureza à qual o liberalismo estava devotado. Mill, que poderia ser considerado o santo padroeiro do liberalismo moderno anglófono, afirmou, em sua Autobiografia

\footnotetext{
${ }^{5}$ Cabe destacar que, nos Estados Unidos, esse aspecto central do liberalismo - da fé nas promessas seculares do futuro - marcou fortemente a esquerda política no século XX. Portanto, no discurso popular americano, "liberal" se confunde com "de esquerda", se bem que muitas vezes de uma maneira superficial. Aqui, o autor faz uma leitura mais precisa das origens e conseqüências do pensamento liberal americano, inclusive sua importância no movimento dos Direitos Civis. (N. do T.)
} 
publicada após a sua morte, que seu colapso aconteceu quando ele reconheceu que, se todos os seus desejos de reforma social acontecessem, ele continuaria infeliz mesmo assim. As reformas podiam satisfazer os cálculos do grande sistema de seu pai - o Utilitarismo -, mas a alma humana ansiava por algo mais profundo. Assim começou a busca de Mill, entre os anseios irracionais e os vôos não científicos do Romantismo Continental, pelos elementos ausentes do liberalismo. ${ }^{6}$

Os liberais nem sempre tiveram tempo de continuar sua busca, mas eles nunca satisfizeram a fome que os levou a ela. James, o filósofo que deu ao liberalismo americano seu traço distinto na era Progressista, aprendeu uma lição parecida de seu "colapso" mental, como ele o chamou. James se convenceu de que as pessoas que se afastavam do pensamento racional poderiam se aperceber de verdades filosóficas profundas e até de verdades científicas. Tais verdades, muitas vezes, iludiam pessoas normais, saudáveis. James explorou essa teoria, aparentemente paradoxal, de forma mais completa em The varieties of religious experience (1903) [As variedades da experiência religiosa]. Mas um ensaio político - um dos ensaios mais famosos de James - sugere a importância desse insight no curso histórico do liberalismo. The moral equivalent of war $[O$ equivalente moral da guerra], publicado em 1910, discutiu a necessidade humana para cruzadas irracionais - por contágios em massa de emoção que, ao contrário da razão, pudessem inspirar sacrifícios e solidariedade. James solidarizava-se com os pacifistas que corajosamente tinham esperança na abolição da guerra, mas ele também afirmava que aqueles que fazem campanha contra "o horror e a irracionalidade da guerra" estavam enganados. O homem civilizado ainda era selvagem - ainda tinha "toda a combatividade inata e todo o anseio pela glória de seus ancestrais". A guerra, apesar de toda a sua insanidade, era emocionante de uma forma que servir ao bem-estar social nunca poderia ser. As pessoas adoravam lutar - ou ao menos adoravam se juntar e começar a lutar. Os exércitos sempre instigavam orgulho no esforço coletivo. Mas aos grupos liberais, social-democratas ou pacifistas só instigavam vergonha - "vergonha ante a idéia de pertencer a tal coletividade". James apoiava os esforços para abolir a guerra e acreditava no "lento advento de alguma forma de equilíbrio socialista”. Mas ele se preocupava com a possibilidade de inspirar as pessoas a

\footnotetext{
${ }^{6}$ John Stuart Mill, Autobiografia (Londres, Longman's, 1873). Mill foi também uma figura central no Liberalism and social action (1935) [Liberalismo e ação social], de Dewey, em Later works XI [Trabalhos posteriores] (Carbondale, Southern Illinois University Press, 1987), de Dewey; ver p. 11, 18, 19, 23.
} 
chegarem pelo menos perto desses objetivos. Em um programa para alcançar bons salários e carga de trabalho pequena, por exemplo, James reclamava:

Onde está a crítica e a precipitação, o desprezo pela vida, quer seja a própria, quer seja a dos outros? Onde está o "sim" e "não" selvagem, o dever incondicional? Onde está o serviço obrigatório? Onde está o derramamento de sangue? Onde está qualquer coisa pelas quais as pessoas poderiam sentir honradas por pertencer?

Os desafios como arriscar a vida para cumprir um dever incondicional, ou enfrentar escolhas claras e urgentes, tais como matar e ser morto: essas coisas entusiasmam as pessoas. Tais desafios livram as pessoas das incertezas individuais e falhas do dia-a-dia. James acreditava na liberdade e no individualismo, mas ele reconhecia que as pessoas muitas vezes querem abrir mão de sua liberdade para se engajarem em uma causa maior. Aqui pode estar o desafio mais importante posto ao liberalismo: não questionar a força de atração dos objetivos liberais, mas a plausibilidade de alcançá-los por meios liberais.

John Dewey, que desempenhou o papel de filósofo patrono do liberalismo americano mais vezes do que qualquer outro depois da morte de James em 1910, foi mais cauteloso e persistente do que James em explorar o que faltava ao liberalismo. No começo da ascensão política dos liberais americanos, em 1929, Dewey observou que "os liberais são notoriamente resistentes a se organizarem". A razão simplesmente não oferecia uma base tão boa para a solidariedade quanto a tradição dos conservadores. Os liberais "têm de depender de idéias ao invés de hábitos em crenças estabelecidas; e quando as pessoas começam a pensar em questões sociais, elas começam a ter diferenças de opinião". Em contraste, escreveu Dewey, os conservadores tinham "um senso natural de coesão... Eles ficam juntos não tanto por suas idéias, mas por hábito, por medo do desconhecido e por um desejo de se apegarem ao que já têm”. Mas os liberais tinham, na melhor das hipóteses, entusiasmos temporários, que sempre acabavam e que não conseguiam mobilizar as massas. Dewey, um naturalista científico que rejeitava a crença em Deus e em outros seres sobrenaturais, passou a acreditar que os liberais podiam se apropriar da inspiração que eles precisavam na religião - embora, para assim fazerem, eles teriam que mudar sua visão sobre religião.

Quase no final do Quest for certainty (1929) [À procura da certeza], Dewey tentou dissociar a crença "religiosa" - que ele achava que podia ser útil aos liberais - da "religião" existente, que seria irracional e retrógrada. Em 1934, em A common faith [Uma fécomum], ele elaborou melhor esta idéia. Religião era 
superstição, imposta por intimidação e propaganda, mas, ao aboli-la, o homem moderno da ciência estaria jogando o bebê fora, junto com a água da bacia, pois a religião estava misturada com muitos dos impulsos mais humanos - impulsos de generosidade e de auto-sacrifício, de humildade e de solidariedade para com o próximo. Embora esses impulsos tenham geralmente sido encontrados na religião, Dewey insistia que eles podiam ser dela liberados, e essa seria uma tarefa urgente. A autoridade religiosa estava diminuindo rapidamente entre as pessoas cultas. Pior ainda, todas as religiões conhecidas estavam corrompendo seus melhores impulsos, perseguindo os que não as abraçavam e fechando-se a novas idéias. Dewey reconhecia a dificuldade de salvar as virtudes religiosas da própria religião. No entanto, ele achava o liberalismo vigente tão insatisfatório como a religião vigente. O liberalismo em sua juventude, durante os séculos XVIII e XIX, tinha sido um credo "de luta". Naquela época, quando os liberais tentavam principalmente destruir os obstáculos manáquicos e feudais ao governo da classe média, o jovem liberalismo tinha arregimentado a classe média capitalista emergente. Mas depois daquela época, o liberalismo se mostrou "quase impotente". Quando "se tratou da questão de organizar novas forças sociais" para expandir e proteger a liberdade que o liberalismo tinha estabelecido, este estagnou e se colocou solidamente em defesa do status quo. Enquanto isso, a liberdade que os liberais tinham defendido era ameaçada por novas forças que os liberais mal podiam compreender, quanto mais lutar contra elas. Esses acontecimentos, escreveu Dewey, obrigaram os liberais a fazer mais do que se limitarem a aprender como recuperar um entusiasmo quase religioso pela liberdade. Os liberais também tinham de reconhecer que, nos tempos modernos, "insegurança material" tinha se tornado a principal ameaça à liberdade, e que "o poder não regulado", no âmbito "privado" das corporações destruía a liberdade tão certamente quanto o poder absoluto destruía a essência pública do governo. Dewey acreditava que os liberais pudessem aprender e moldar essas novas forças - na verdade, eles tinham que dominar essas forças, para se salvarem e para salvar a civilização.

Apesar de toda a rigidez e decadência do liberalismo vigente, Dewey acreditava que o liberalismo ainda tinha valores "preciosos" em seu âmago. Mais importante ainda, ele não via qualquer fonte alternativa de valores humanos. Em retrospecto, talvez não seja surpreendente que Dewey não tenha conseguido concluir satisfatoriamente seu ciclo vital. Ele nunca explicou como assegurar as bênçãos da fé em seu programa secular. Para seu crédito, ele nunca fingiu ter feito isso. Ele se ocupou dessa questão e demonstrou a sua importância e dificuldade, aparentemente sem perder a fé de que ela poderia 
ser resolvida algum dia. Dewey queria um controle humano razoável da sociedade - ele não ansiava por poderes além da compreensão humana. Dewey conseguiu menos ainda encontrar uma forma popular de fazer um híbrido de fé e agnosticismo - de convicção e incerteza - junto aos americanos, que, desde o final do século XVIII, foram um dos povos mais religiosos do mundo. Tanto quanto eu saiba, Dewey tentou com mais consciência e persistência do que qualquer de seus contemporâneos descobrir tal híbrido. Mas o que é importante para os presentes propósitos é que Dewey compartilhava com muitos outros liberais este sentimento - vindo de Mill, James, e outros (Auguste Comte, Josiah Royce, George Eliot, Emile Durkheim, para citar alguns) - de que era preciso urgentemente um substituto moderno para a religião.

No final da década do New Deal, Malcolm Ross, outro pensador e ativista liberal, expressou a ânsia por inspiração e solidariedade em termos mais terrenos do que Dewey. Ross veio a se tornar famoso mais tarde como diretor do Comitê de Práticas de Emprego Justo na Segunda Guerra Mundial e foi um dos primeiros liberais não-sulistas a ganhar experiência em política racial. Ele aparentemente terminou os anos 1930 exausto. A autobiografia de Ross de 1939, Death of a Yale man (A morte de um homem de Yale), exibe a história de um homem desiludido antes do tempo. Ross dirigiu suas reflexões para sua juventude como repórter nos anos 1920, quando sua vida fora cheia de vigor e aventura. Naqueles tempos, suas tarefas incluíam a cobertura dos revivals de Billy Sunday em Louisville. Desse evangelista - ex-vendedor, ex-jogador de baseball e ex-dono de funerária, que aceitava a ajuda da Ku Klux Klan e converteu dezenas de milhares de pessoas -, Ross escreveu em 1939: "Há uma certa dignidade em qualquer um bastante envolvido em sua profissão, e Billy era excepcional no negócio de salvar as almas dos emotivos". Sunday estava perto do fim de sua carreira quando Ross o entrevistou durante uma viagem de trem pelo país. Olhando para trás, em 1939, Ross se dizia "satisfeito por ter visto o último daqueles que poderiam tomar a América de assalto com uma plataforma de inferno e danação". ${ }^{7}$ Mas Ross se recompôs e acrescentou, como H. L. Mencken ou Sinclair Lewis, que ele quis dizer que estava satisfeito "porque a América tinha [até 1939] saído do estágio em que os donos das vendas poderiam subsidiar um revivalist para atrair multidões para a cidade". O cinismo liberal de Ross sobre a religião evangélica o impediu de assumir compromissos próprios com a religião. Mas, por sua própria ironia, Ross ansiou

\footnotetext{
${ }^{7}$ Caso não seja óbvio, apresso-me em afirmar que a predição de Ross estava completamente errada. Ele não podia ter dado conta da emergência de Billy Graham, Martin Luther King, ou líderes populares evangélicos de anos posteriores, como Jimmy Carter, Jerry Falwell, Pat Robertson, Jesse Jackson e George W. Bush.
} 
"Senhor Todo Poderoso, se seu servo Billy Sunday tivesse sido um homem com uma fala honesta para dizer às pessoas onde é que elas deveriam se posicionar e a que causa deveriam direcionar seus corações, que sacudidela saudável esses encontros poderiam ter causado em Louisville". Ross culpou os "donos das vendas" por somente permitirem que uma salvação pessoal do outro mundo pudesse ser ensinada na cidade, assim como culpava seu próprio jornal por estar de acordo com esses comerciantes: "Quisera ter tido a inspiração de perguntar a Billy Sunday... o que ele pensava das batalhas do campo das minas de carvão que estava acontecendo no outro lado de Kentucky. Isso teria dado uma boa história, e eu provavelmente deveria ter sido despedido por criá-la".

Para Ross, a religião era uma distração com o outro mundo que desviava a atenção dos problemas sociais reais. Ele não culpava inteiramente os donos de lojas e de jornais reacionários por tal conspiração, pois Ross se recusava a falar das limitações da natureza humana. Em vez disso, como fazem os liberais, ele refletia tristemente sobre os limites dos que tinham tido uma educação pior que a dele. Que o sofrimento dos mineiros de carvão nunca tenha sido mencionado quando Billy Sunday estava na cidade, em grande parte porque ele estava na cidade, ilustrava tão-somente "nossa preferência tradicional pela emoção em detrimento da realidade".

O arrependimento de Ross, como o sentimento de Dewey de que o liberalismo carecia de uma fé sólida, é um tema que percorre o pensamento liberal. Poderia ser chamado de inveja do púlpito (para tomar emprestado um termo de Ann Douglas, que o usou em um contexto distinto). O famoso autor e defensor do New Deal, Thurman Arnold - a quem Franklin Roosevelt designou para ficar à frente do seu programa antimonopólio em 1937 -, expressou este sentimento em seus livros populares: The symbols of government (1935) [Os simbolos do governo] e The folklore of capitalism (1937) [O folklore do capitalismo]. Significativamente, proponentes do New Deal, como Ross e Arnold, compartilhavam esse sentimento com o mais importante liberal "independente", Dewey, que ficou fora do New Deal e o criticou por fazer muito pouco. Eles também compartilhavam esse sentimento com Walter Lippman, o intelectual liberal mais famoso de todos, que, em seu The good society (1937) [A boa sociedade], criticou o New Deal por fazer demais. Finalmente, eles o compartilhavam com o principal liberal republicano, Glenn Frank, que coordenou o esforço bem-sucedido de levar o GOP a concordar com as despesas do New Deal e com a indicação de Wendel Willkie, em 1940. ${ }^{8}$ Como era de se esperar, a percepção de uma ausência espiritual fundamental no âmago do

\footnotetext{
${ }^{8}$ Esses e outros exemplos aparecem em mais detalhe em Chappel, A stone of hope.
} 
liberalismo se intensificou depois dos choques da Segunda Guerra Mundial, incluindo a morte repentina do único líder liberal nacionalmente popular, Franklin Roosevelt. ${ }^{9}$

O melhor exemplo de inveja do púlpito liberal do pós-guerra foi o livro muito influente de Lionel Trilling, de 1949, The liberal imagination [A imaginação liberal], que defendia que os liberais precisavam aprender com seus inimigos conservadores a arte de invocar os mitos e símbolos irracionais. Mas esse jogo era mais difícil do que nunca para os liberais do pós-guerra: depois da Segunda Guerra Mundial, a inveja liberal da mobilização religiosa persistiu, mas o temor dos liberais de cruzadas irracionais parecia aumentar. Afinal das contas, eles tinham acabado de ver como tais apelos tinham sido contagiosos quando feitos às massas na Alemanha, Rússia e - como eles reconheceram em 1949, se não antes disso - na China. O liberalismo do pós-guerra foi identificado com "o centro vital” e com o desprezo à "ideologia”. A ideologia significava: um corpo de noções mobilizadoras ou integradoras, necessariamente extremas, que apelavam às pessoas da mesma forma que faziam as religiões, mas que podiam ser ainda mais danosas do que a religião, como o Nazismo, o Fascismo, o Stalinismo e o Maoísmo pareciam ser. Embora eu não possa provar a afirmação, suspeito que, de alguma forma, os americanos adquiriram seu hábito estranho de pronunciar a palavra com um $i$ curto - como se sua raiz fosse $i d i o t$, em vez de Idea - durante este período.

\footnotetext{
${ }^{9} \mathrm{Na}$ década posterior à Segunda Guerra Mundial, os liberais se sentiram cada vez mais identificados com a oposição ao racismo. Eles não tinham se sentido muito identificados, em sua maioria, antes da Segunda Guerra Mundial. Graças ao surgimento crescente da militância negra durante a guerra - ao lado da revolta contra o racismo nazista e a necessidade política de garantir o voto negro no Norte e para os aliados no mundo em processo de descolonização -, os liberais passaram a apoiar os direitos dos negros. Os eleitores passaram a identificar esses direitos, cada vez mais, como uma questão que definia os liberais. O surgimento crescente (rising wind) se refere a acontecimentos como o movimento da marcha parcialmente bemsucedida de A. Philip Randolph em Washington, que reuniu 100 mil simpatizantes e teve o mérito de forçar Roosevelt a publicar uma Ordem Executiva (número 8.802, 15 de junho de 1941), terminando com a discriminação racial na indústria militar; o aumento de $900 \%$ no número de associados à NAACP, de 50 mil para 450 mil (355 para 1.073 sedes regionais) durante a guerra; e, sobretudo, o aumento da migração negra do sul rural para as cidades do norte, onde, de repente, homens e mulheres de cor negra passaram a ter direito ao voto - e, talvez mais importante ainda, a entrada deles em estados de dois partidos políticos, em que eleições apertadas fizeram com que ambos os partidos tivessem de competir pelo "bloco negro". A Suprema Corte baniu as eleições primárias brancas em 1944 e em 1948, e Harry Truman - um dos menos liberais dos líderes Democratas - ordenou a dessegregação das forças armadas; esse último foi o avanço mais radical na política de direitos civis desde a Reconstrução, e até hoje o mais bem-sucedido.
} 
Os liberais da guerra fria - aqueles que sobreviveram ao anticomunismo e mantiveram uma certa influência política nos finais da década de 1940 e nos anos 1950 - contavam com um solo fértil para transferir um novo pessimismo sobre a União Soviética para seu liberalismo. Eles teciam elogios insinceros à antropologia antiliberal de Reinhold Niebuhr, a quem George Kennan chamava, segundo se afirmava, de "o pai de todos nós". Niebuhr fez seu nome na história da intelectualidade desacreditando impiedosamente da confiança liberal na natureza humana, especialmente em seu maior livro, Moral man and immoral society [O homem moral e a sociedade imoral], publicado em 1932, quando Niebuhr era um socialista. Como muitos da esquerda americana, Niebuhr aparou suas diferenças com os liberais centristas vitais nos anos 1940, a fim de formar uma frente unida contra Stalin. Aqueles liberais, por seu turno, afirmavam que tinham amadurecido sob a influência disciplinadora de Niebuhr. A maioria dos historiadores não notou, no entanto, que esse ceticismo recém-descoberto dos liberais se aplicava quase inteiramente à natureza humana no estrangeiro, não à natureza de sua própria sociedade. Animados pela vitória na Segunda Guerra Mundial e pelo avanço econômico exclusivamente americano, os liberais americanos permaneceram otimistas como nunca sobre a vida nos Estados Unidos. Quando pensavam sobre política doméstica, os liberais se reportavam a seu otimismo inato - sua fé inabalável no progresso gradual e voluntário que era, enfim, sua única pedra fundamental. Pode ter sido necessário a eles equilibrar um novo pessimismo sobre a União Soviética com o otimismo sobre os Estados Unidos, onde, é preciso que se diga, a economia cresceu em velocidade aparentemente milagrosa, e a educação se expandiu no mínimo na mesma velocidade. O otimismo liberal acerca de questões domésticas se estendeu até para a vida para minorias raciais americanas.

Em relação à raça, os liberais sacaram seus palpites de um dos livros mais otimistas do século XX: o relatório grandioso de Gunnar Myrdal, publicado em 1944, An american dilemma: the negro problem and american democracy [Um dilema americano: o problema do negro e a democracia americana], que alcançou 1.483 páginas. O maior testemunho do otimismo de Myrdal em relação à natureza humana pode residir em sua aparente dedicação à proposição de que seres humanos fossem ler tantas páginas de dados e de análise sobre um problema social. Mas seu otimismo teve ampla recompensa: o livro se tornou 
um best seller, muito comprado e citado, senão lido. ${ }^{10}$ É extraordinário quão pouca crítica negativa o relatório de Myrdal teve na época, considerando o quanto os acadêmicos o discutem agora. Para ser justo, An americand dilemma permanece sendo a mais completa coleção de dados jamais compilados sobre o racismo americano à época da Jim Crow. Talvez ainda mais impressionante do que a própria conquista de Myrdal foi sua habilidade de recrutar, como seus colaboradores, muitos dos mais famosos cientistas sociais do país - e depois levá-los à concordância e até à clareza de suas posições. O argumento do livro não influenciou o pensamento liberal tanto quanto codificou e justificou o que os liberais já acreditavam, ou queriam acreditar, sobre raça. A prática americana de discriminação racial, Myrdal afirmou, estava em conflito com o "credo americano" - sua famosa expressão para a devoção apaixonada dos americanos de oportunidade igual para todos. O conflito na psique americana entre prática e credo foi o motivo do otimismo de Myrdal. Ele insistiu que este conflito não podia continuar por muito mais tempo: a desigualdade sistemática tinha de ceder lugar ao compromisso mais forte e mais amplo com a igualdade - uma variação em torno do tema original liberal de que a razão triunfará sobre a tradição.

Uma coisa que o relatório de Myrdal não fez foi dar aos liberais a inspiração para construir solidariedade e compromisso com o auto-sacrifício. Alguns deles, como Trilling, ainda se queixavam da ausência de tal inspiração. Há uma grande ironia em relação ao antipessimismo militante de Myrdal: seu otimismo se tornou uma forte justificativa para a não-ação. $\mathrm{O}$ otimismo dos liberais os fortalecia na medida em que eles, cada vez mais, se decidiam em favor dos direitos civis como questão prioritária. Antes da Segunda Guerra Mundial, os direitos civis tinham sido evidentemente desprestigiados, se chegassem

${ }^{10}$ O famoso relatório de 1947 elaborado pelo comitê especial sobre direitos civis do presidente Truman, To secure these rights [Para assegurar esses direitos],é pouco mais do que uma tradução de Myrdal. O comitê falava de um "credo americano" em conflito com a prática de discriminação racial e do triunfo necessário da crença sobre a prática. Roy Wilkins da NAACP afirmou que o relatório do comitê de Truman tornou-se "um modelo que usamos pelas próximas duas décadas". Hubert Humphrey (senador e depois vice-presidente), que foi secundour Truman na pressão sobre os Democratas para que apoiassem os direitos civis no final dos anos 1940, foi também fortemente influenciado por Myrdal - que leu antes de entrar para a política - e mais tarde fez eco em seus discursos. Quando a Corte Suprema finalmente colocou em julgamento a legalidade da segregação em 1954, o relatório de Myrdal figurou de forma importante em sua decisão. Myrdal foi considerado uma grande autoridade pela imprensa liberal e por livros liberais como Inside U.S.A. [Por dentro dos Estados Unidos], de John Gunther (1952). Sobre a grande influência de Myrdal, ver Walter Jackson, Gunnar Myrdal and America's Conscience (Chapel Hill, 1990), e David Southern, Gunnar Myrdal and Black-White Relations (Baton Rouge, 1987). 
a constar, na agenda liberal. Durante os anos 1940 e 1950, os jornais liberais publicavam cada vez mais editoriais e notícias sobre a questão racial, mas essas reportagens focalizavam-se quase exclusivamente em atrocidades tais como o linchamento. As reportagens e os editoriais tratavam a degradação ou humilhação racial como um crime - uma violação anormal contra a sociedade - em vez de parte de seu tecido normal. Na época, os liberais - incluindo a NAACP - concordavam que o crime de linchamento estava em drástico declínio, com somente um ou dois por ano nos princípios dos anos 1950. Essas estatísticas (como sabemos agora, graças ao historiador Chris Waldrep) estavam completamente erradas. Ademais, o linchamento legal, como alguns já estavam chamando a pena capital, poderia simplesmente ter feito o trabalho da turba de forma mais eficiente: a pena de morte, tanto naqueles tempos quanto hoje, foi aplicada primordialmente a homens negros do sul. ${ }^{11}$

Assegurados por Myrdal e inúmeros livros, artigos e relatórios que faziam eco a Myrdal, os liberais não sentiam necessidade de reordenar suas prioridades para enfrentar a prática sistemática de segregação até que a luta chegou às ruas em meados da década de 1950. Como o historiador Walter Jackson observa: "A última coisa que os liberais brancos estavam esperando nos anos 1950 era um movimento de massa entre os afro-americanos no sul". O movimento veio como uma enorme surpresa, para a qual os liberais não estavam preparados, principalmente porque seu próprio liberalismo não tinha qualquer base para sustentar o engajamento e o sacrifício que os boicotes, os sit-ins e as prisões exigiam, e porque o seu otimismo myrdaliano os cegava à necessidade de tais estratégias. Eles não podiam fazer o que o movimento de direitos civis fazia.

${ }^{11}$ Para uma discussão dos periódicos liberais nos anos 1940 e 1950, ver Peter Kellog, Northern Liberals and Black American: A History of White Attitudes, 1936-1952 (Ph.D. Diss., Northwestern University, 1972). Waldrep argumenta convincentemente que os dados sobre linchamento usualmente citados eram baseados em pressuposições e definições conflitantes, a ponto de instaurar a dúvida em relação às generalizações sobre o crime - incluindo a noção universalmente aceita de que o linchamento diminuiu em meados do século XX: "War of Words: The Controversy over the Definition of Lynching, 1899-1940", Journal of Southern History, LXVI (Fev. 2000), 75101. Journal of Southern History, LXVI (Fev. 2000), 75101. Para considerações sobre se "linchamento legal" era mais letal do que a atividade mais anárquica da multidão enfurecida, ver George Wright, Racial Violence in Kentucky, 1865-1940: Lynchings, Mob Rule, and "Legal Lynchings" (Baton Rouge, 1990); W. Fitzhugh Brundage, Lynching in the New South: Georgia and Virginia, 1880-1930 (Urbana, 1993); Brundage, ed., Under Sentence of Death: Lynching in the South (Chapel Hill, 1997); Stewart Tolnay and E.M. Beck, A Festival of Violence: an Analysis of Southern Lynchings, 1882-1930 (Urbana, 1995), e a breve discussão da questão em A Stone of Hope. 


\section{Uma minoria profética}

Aqueles que surpreenderam os liberais nos meados dos anos 1950, com suas manifestações nas ruas, mantiveram a pressão de seu protesto - um protesto geralmente disciplinado e eficiente - por cerca de dez anos. A pressão durou tanto que forçou o governo dos Estados Unidos a tomar a atitude radical de destruir a segregação e o sistema de privação de direitos. O governo foi especialmente vulnerável a essa pressão, porque estava competindo com os russos para alianças na Ásia e África pós-colonial, e porque milhares de eleitores negros tinham migrado para estados com dois partidos políticos, forçando os Democratas a competirem com os Republicanos por sua aliança. O novo "voto em bloco" negro foi entendido como "o equilíbrio de poder" em vários estados do norte. No entanto, o governo federal, sob Eisenhower e Kennedy, continuou bastante relutante até que a desordem nas ruas do sul causou revolta suficiente no norte e no exterior. Meu livro, A stone of hope:prophetic religion and the death of Jim Crow (2003) [Uma pedra de esperança: religião profética e a morte da Jim Crow], se concentra em sete líderes dos direitos civis em relação aos quais consegui reunir um registro intelectual suficientemente detalhado de suas opiniões sobre a natureza humana. No presente artigo, vou abordar brevemente apenas três deles: Martin Luther King, Bayard Rustin e Modjeska Simkins.

Os liberais, incluindo Gunnar Myrdal, eram cegos às opiniões dos líderes negros ou desconsideravam a evidência de um conflito entre seu próprio otimismo e o ceticismo dos líderes negros. ${ }^{12}$ Myrdal insistiu, em 1944, que a maioria dos negros estava resistindo à influência de W. E. B. DuBois e alguns outros que tinham se tornado "pessimistas". A maioria dos negros, afirmou Myrdal,

${ }^{12}$ Os liberais, incluindo muitos da assim chamada esquerda no mundo acadêmico, ainda estão cegos em relação à sua dependência de um mito de progresso - que vê o movimento de direitos civis como parte de uma história mais ampla de expansão da liberdade e participação política. Essa história do progresso vai do declínio de deferência no período colonial tardio, culminando com a guerra de independência americana e com o estabelecimento do governo representativo em toda a nação, passando pela abolição da escravidão no Norte, a abolição das qualificações de propriedade para o voto, a elevação ainda maior do "homem comum" na era de Jackson; a abolição da escravidão e o breve momento de participação política do negro no Sul durante a Reconstrução; o direito de voto das mulheres nos territórios e estados do Oeste, posteriormente em toda a nação em 1920; o maior reconhecimento dos direitos e do poder da classe trabalhadora nas eras Progressiva e do New Deal. A progressão finalmente termina com a Segunda Reconstrução e a subseqüente "revolução de direitos" para as mulheres, os imigrantes recentes, as minorias étnicas nativas e muitas pessoas cujas práticas sexuais tinham sido antes consideradas desviantes. Mesmo o amplo uso do termo backlash (reação) - significando um desvio anormal e irracional em relação ao adequado curso na direção de uma liberdade mais inclusiva - revela a força da crença liberal no progresso. 
não tinha "perdido sua crença de que, em última instância, o credo americano [de oportunidade igual para todos] iria prevalecer". Os negros tinham ainda mais fé do que os brancos, disse Myrdal, na "magia da educação".

É impossível dizer se Myrdal tinha razão sobre a população negra em geral, mas, embora eu não tenha tentado um levantamento científico da evidência disponível, a opinião da população negra da época parece mais heterogênea do que Myrdal admitiu. Os maiores jornais voltados para o público negro no período - Crisis, Phylon, Midwest Quarterly, Negro Quarterly, Journal of Negro Education - exibem um equilíbrio de otimismo e pessimismo. Esse equilíbrio também está evidente nas opiniões dos leitores e colunas de cartas à redação de tais jornais negros, como o Pittsburgh Courier, Michigan Chronicle, Los Angeles Sentinel e Baltimore Afro-American. Dois best sellers literários que definem o período de Myrdal, o Native son [Filho nativo], de Richard Wright, e o Invisible man (1952) [O homem invisível], de Ralph Ellison - provavelmente o romance negro mais lido do século nos Estados Unidos - teriam de ser considerados entre os mais pessimistas dos livros populares do século XX, de modo nenhum refletindo o otimismo que Myrdal atribuiu às massas negras. ${ }^{13}$ Talvez, como a maioria dos povos, os negros americanos eram, ao mesmo tempo, otimistas e pessimistas, mas não podemos dizer nada baseados na evidência bruta que nos está disponível - e que estava disponível a Myrdal. O que podemos conhecer são as visões de um número relativamente pequeno de estrategistas negros que estavam engajados no movimento e que deixaram arquivos detalhados de seus pensamentos. Estes claramente não sustentam a visão de Myrdal. Ao passo que Myrdal e os liberais americanos estavam comprometidos com o otimismo a respeito do desenvolvimento humano, e especialmente das instituições humanas, os pensadores do movimento de direitos civis se destacam por sua rejeição a este mundo e a suas tendências naturais. Eles se destacam por sua recusa em admitir que os processos sociais se desenvolvam independentemente e por sua falta de fé no poder da educação e do desenvolvimento econômico para curar a sociedade dos demônios opressivos. Em suas concepções da natureza humana, eles estão mais afinados com os profetas hebraicos, a quem eles citam, ou para citar exemplos modernos, Frederick Douglass e Reinhold Niebuhr, do que com os liberais mais influentes. Embora Martin Luther King claramente tenha um grande débito para com a teologia liberal em relação a muitas questões (incluindo sua aversão pelo que ele chamava de

${ }^{13}$ É interessante que estes livros pudessem ser best sellers no mesmo período que o best seller incrivelmente otimista de Myrdal. 
"fundamentalismo" de seu pai), ele passou a rejeitar bem cedo o otimismo liberal sobre o homem. ${ }^{14}$ Meu argumento não é o de que King tenha sido não liberal acerca de outras questões, como as obrigações sociais da igreja ou a interpretação simbólica da história bíblica; todavia, sua doutrina da natureza humana é mais importante do que tem sido reconhecido - talvez muito mais importante do que sua crença social liberal - na explicação de sua carreira como líder de direitos civis e na definição do terreno comum de discussão que compartilhava com outros líderes do movimento pelos direitos civis. A visão de King do homem chega muito mais perto do que ele (imprecisamente) chamava "a nova ortodoxia" - que ele entendia como a crença de Reinhold Niebuhr na depravação inerente ao homem organizado - do que do liberalismo tradicional. Nos ensaios que ele escreveu de 1948 a 1951 no Crozer Theological Seminary [Seminário Teológico Crozer], King faz eco com o pessimismo dos profetas sobre o homem. Esse pessimismo surge com bastante clareza em um ensaio de 1948 sobre o Jeremias, no qual King delineou a maior parte dos temas que ele iria mais tarde enfatizar em seus discursos políticos: a nação está numa crise moral; as instituições humanas, incluindo as igrejas e os templos, são corruptas; a sociedade rejeita os profetas que dizem a verdade (King afirmou que Jeremias era um fracassado pelos padrões do mundo); e, finalmente, a verdade profética motiva a rebelião e a renovação.

Sobre este último ponto, King escreveu que Jeremias, ao articular a segunda aliança, estava corrigindo a inocência dos proponentes do Deuteronômio, que, apesar de todos os sucessos em organizar sua religião, "não viram que a religião não é algo que pode ser organizado, sendo, em seu lugar, a corrente espontânea do contato do homem com um espírito divino". O templo era "uma instituição nacional, intimamente ligada às fortunas da raça". Assim, "atacar" o templo era se comprometer, como o fez Jeremias, com a rebelião política e social, bem como religiosa. King chamou Jeremias - um favorito dele juntamente com Isaías, Amos e Jesus — de "o Profeta Rebelde”. Jeremias "apegou-se a uma verdade revolucionária" e ficou sendo "um brilhante exemplo da verdade contida na idéia de que a religião nunca deveria sancionar o status quo". King não comentou sobre o American Dilemma de Myrdal até terminar os estudos, mas explorou algo paralelo ao tema de Myrdal - o que

\footnotetext{
${ }^{14}$ Uma das reivindicações de $A$ stone of hope é que os acadêmicos incorrem em erro ao afirmar que King se tornou pessimista somente nos últimos dois ou três anos de sua vida. A evidência mostra, ao invés disso, que King consistentemente rejeitava a antropologia otimista, desde seus dias de seminário, no final dos anos 1940.
} 
ele chamou o "dilema teístico" - em um ensaio de 1948 sobre o "problema" do mal. Teístas como ele próprio, King escreveu, têm um dilema: sua fé diz a eles que o poder "por trás de todas as coisas é bom". Mas os fatos da vida cotidiana parecem contradizer essa fé. Como cristão, King tinha de acreditar (como ele afirma em um ensaio anterior) na "esperança escatológica": após a Segunda Vinda do Senhor, a justiça, a paz e a bondade reinariam. Mas ele também insistiu na necessidade de ser realista sobre a vida do homem nesta terra antes da Segunda Vinda do Senhor. Ele citou a afirmação de Stuart Mill de que "quase todas as coisas pelas quais os homens são enforcados ou postos na cadeia por fazerem uns com os outros são eventos diários da natureza. A natureza mata, incendeia, causa fome, congela, envenena".

King repetidamente escreveu, fazendo eco às palavras de Jeremias e Jó, que a história mostra "o justo sofrendo, enquanto que o injusto prospera".

O mal era "abundante" no universo: "somente o otimista superficial que se recusa a enfrentar as realidades da vida deixa de ver esse fato óbvio".

A insistência de King de que o problema do mal não podia ser completamente resolvido, ao menos não nesta terra, era incompatível com qualquer crença myrdaliana de que a culpa psíquica iria obrigar uma nação a desistir das práticas do mal. A mensagem de King chegou a um ponto pragmático e político quando ele liderou o boicote de Montgomery em 1955 e a Southern Christian Leadership Conference [Conferência da Liderança Cristã do Sul] em 1957: o povo que havia sofrido tanto tinha que sofrer ainda mais para se livrar da injustiça. Essa é a injustiça maior ("ironia” parece uma palavra fraca demais) da opressão: aqueles que já pagaram o preço da injustiça têm de pagar mais ainda para desfazer a injustiça, enquanto os perpetrantes e beneficiários da injustiça podem se livrar inteiramente dela e, na verdade, provavelmente acharão uma forma de se beneficiarem da diminuição da injustiça. Essa situação era lamentável, porém inevitável. Os oprimidos são os únicos que arcarão com o peso da luta contra sua opressão, porque eles são os que têm interesse de assim o fazer: os únicos que não têm nada a perder. Esperar que a história seguisse qualquer outro caminho seria perigosamente inocente.

King exortou todos a fazer sempre sacrifícios cada vez maiores - que, por si só, daria a eles a medida de seu poder, mesmo que eles nunca vivessem para ver os frutos de seu poder: o sofrimento criativo era a única saída. Os sermões de King sempre retornavam à mensagem: "Sofrimento não merecido é redentor". O sacrifício era a chave de sua estratégia de ativismo. 
Bayard Rustin exerceu uma forte influência oculta sobre King e vários líderes de protestos depois dele. Rustin tinha sido um membro da Liga Comunista da Juventude antes de rejeitar os comunistas e se filiar aos pacifistas na Fellowship of Reconciliation (FOR) [Sociedade de Reconciliação], sendo preso por resistir ao serviço militar obrigatório durante a Segunda Guerra Mundial. Em 1942, ele vislumbrou a crise que iria acontecer nas relações raciais: "O cidadão negro, em geral, perdeu a confiança nos brancos da classe média”, ele escreveu. "Em sua hora de aflição, ele não procura 'conversa' e sim ação dinâmica. Ele vê com medo e desconfiança a idéia da classe média de educação e de mudanças culturais a longo prazo.” Ao adotar a não-violência, Rustin não demonstrava purismo moral ou fé na consciência do opressor. A ação não violenta, para ele, era uma espécie de força - com freqüência a única força prática disponível - para obrigar os inimigos a fazerem concessões contra sua vontade. E ela era perigosa: "A não-violência como método tem embutida a exigência de sacrifício terrível e sofrimento longo, mas, como Gandhi disse, 'a liberdade não cai do céu'. Tem-se que lutar e querer morrer por ela". ${ }^{15}$

Rustin, um ex-Quaker, não era tão religioso como King, mas ele via Jesus como um exemplo positivo. "Este fanático cuja insistência no amor atingiu os próprios pilares da sociedade estável”: assim Rustin descrevia Jesus em uma saudação de Páscoa a seus seguidores em 1952. Todos viam Jesus como muito problemático; Rustin notou, mas nem mesmo a crucificação pôde fazer com que se livrassem d'Ele. "A Páscoa, em qualquer época... relembra a iminência da vitória impossível, o poder do fraco impotente." Rustin escreveu que os seguidores de Jesus "precisam ser lembrados que a Páscoa éa realidade, e que as estruturas assustadoras de pompa e poder estão em processo de desintegração no momento de sua maior força”. Rustin certamente sabia que estava fazendo eco ao desdém dos profetas hebraicos às instituições humanas, mas ele não podia saber, em 1952, quase quatro anos antes de conhecer Martin Luther King, que ele estava antecipando profeticamente uma expressão-chave no maior discurso de um novo profeta: "A Páscoa é o símbolo da esperança ressuscitada do túmulo da falta de esperança”.

\footnotetext{
${ }_{15}^{15}$ Rustin, "The negro and nonviolence", Fellowship, Out. 1942, reimpresso em Down the line: The collected writings of bayard Rustin (Chicago, Quadrangle, 1971), p. 8-12. O melhor trabalho sobre a vida e o pensamento de Rustin é Bayard Rustin: troubles I've seen [Bayard Rustin: problemas que eu vi], de Jervis Anderson (Nova York, Harper, 1997).
} 
Em fevereiro de 1956, Rustin foi ao sul conhecer King e oferecer seu conhecimento tático de guerra não violenta. ${ }^{16}$ Em 1956, escrevendo em nome de King, Rustin publicou uma explicação da nova fase da luta pela liberdade dos negros. Embora Rustin não tenha mencionado nominalmente Myrdal, refutou a parte central de sua tese. Ele começou aceitando as duas primeiras premissas de Myrdal: valores fundamentais americanos estavam em conflito com a prática prevalente americana de discriminação, e este conflito criava stress psíquico. Nas palavras de Rustin: "Em suas relações com os negros, os brancos descobriram que eles tinham rejeitado a parte central de suas próprias crenças éticas. Eles não podiam encarar o triunfo de seus instintos menores e ao mesmo tempo terem paz interior". Mas a conclusão de Rustin era diametralmente oposta à de Myrdal. A prática Rustin mantinha, vencia as crenças éticas e, em última instância, as crenças éticas desapareciam. De acordo com Rustin, os brancos "racionalizavam" sua desumanização dos negros, "insistindo que o infeliz negro, sendo menos humano, merecia e até mesmo gostava do status de categoria inferior. Eles argumentavam que sua posição social, econômica e política inferior era boa para o negro". Os brancos chegaram à conclusão de que o negro era simplesmente um caso à parte de sua crença generalizada no progresso, e, dessa maneira, qualquer dissonância cognitiva que os brancos pudessem ter sentido desapareceu. "Os brancos esqueceram que a cultura social do Sul e todas as suas instituições tinham sido organizadas para perpetuar essa racionalização", Rustin escreveu. Os sulistas brancos "observavam um sistema de castas e rapidamente se condicionaram a acreditar que seus resultados sociais, que eles tinham criado, refletiam fielmente a natureza inata e verdadeira do negro". O que fez essa situação ser, no final das contas, temporária, não foi um conflito no interior do branco, como Myrdal acreditava, mas sim as mudanças no lado negro da linha de cor. Rustin escreveu:

Pouco a pouco, as massas de negros no Sul começaram a se reavaliar - um processo que iria mudar a natureza da comunidade negra e condenar fatalmente os padrões sociais do Sul. Assim fazendo, descobrimos que nunca tínhamos realmente reprimido nosso auto-respeito e que não estaríamos em paz com nós mesmos sem o afirmar. Daquele momento em diante, a terrível paz do Sul foi rapidamente solapada pelo pensamento novo e corajoso do negro e sua prontidão, sempre crescente, em se organizar e agir. ${ }^{17}$

${ }^{16}$ Easter Greeting [Saudação de Páscoa], s.d. [cerca de 1952], Bayard Rustin Papers, em microfilme, rolo 20.

17 [Rustin] Martin Luther King, "Our Struggle”, Liberation I (Abr. 1956), p. 38. David Garrow identifica a autoria de Rustin em Bearing the Cross [Carregando a Cruz] (Nova York: Morrow, 1986), p. 73. 
Modjeska Simkins, secretária do South Carolina Branch da NAACP [Escritório Regional da Carolina do Sul da NAACP], nunca se tornou uma personalidade nacional como King e Rustin, mas ela era uma espécie de lenda em seu estado. Simkins também tinha uma visão catastrófica e pessimista da história humana. O modelo de ativista que ela invocou foi o de Jó, cuja história é mais profética e mais pessimista sobre a vida na terra do que a dos profetas propriamente ditos. Jó manteve sua fé ante a mais completa pobreza, isolamento e derrota. Simkins invocou Jó e ocasionalmente Jesus e outros heróis bíblicos como modelos admiráveis. Ainda mais importante, ela os invocou como modelos realistas e práticos da ação política moderna.$^{18}$ Embora Simkins representasse a NAACP, uma organização secular e burocrática - o tipo de instituição no qual Myrdal tinha fé -, ela era uma pensadora profundamente religiosa e radical. Como tal, fazia parte de um padrão de divergência que os historiadores recentemente têm notado entre o escritório nacional da NAACP e o tom e as táticas de muitos ativistas regionais da organização. ${ }^{19}$ Como a maioria dos profetas, Simkins era tão radical em relação à religião ordinária quanto em relação à simples descrença. Ela denunciava "a marca de 'Cristianismo' made-in-America", que "fedia até os céus. Vivendo aqui no 'Cinturão Bíblico', suplantamos o resto da Nação em bater no chão de nossas igrejas e profanar nossas auto-estradas com outdoors repletos de versos bíblicos. Inscrever esses versos no fundo de nossos corações e vivê-los no dia-a-dia são outros quinhentos". Simkins pontuou essa lição citando a admoestação de

\footnotetext{
${ }^{18}$ As melhores fontes sobre a vida e o pensamento de Modjeska Simkins são longas entrevistas feitas por Jacquelyn Dowd Hall em 1974 e 1976; as transcrições encontram-se na coleção Southern Oral History Program, Wilson Library, University of North Carolina, Chapel Hill. Os documentos de Simkins estão na South Caroliniana Library [Biblioteca South Caroliniana], anexo da Modern Political Collections [Coleções de Política Moderna], University of South Carolina [Universidade da Carolina do Sul], Columbia. Quase todo o trabalho secundário sobre ela é de Barbara Woods, também conhecida como Barbara Aba-Mecha. IVer Aba-Mecha, "Black Woman Activist in Twentieth-Century South Carolina: Modjeska Monteith Simkins" ["Ativista Negra na Carolina do Sul no Século XX: Modjeska Monteith Simkins"] (tese de doutorado, Emory University, 1978); Aba-Mecha, "Conferência da Carolina do Sul da NAACP: Origem e Mais Importantes Conquistas, 1939-1954”, Proceedings of the South Carolina Historical Association (1981): 127 (incluindo comentário de Jack Bass e Charles Joyner); e Woods, "Modjeska Simkins and the South Carolina Conference of the NAACP, 1939-1957" ["Modjeska Simkins e a Conferência da Carolina do Sul da NAACP] em Women in the Civil Rights Movement [Mulheres no Movimento de Direitos Civis (Brooklyn: Carlson, 1990), p. 99-120].

${ }^{19}$ Adam Fairclough tem sido particularmente incisivo neste ponto. Ver sua Race and democracy: the civil rights struggle in Louisiana [Raça e democracia: a luta pelos direitos civis na Louisiana], 1915-1972 (Athens, Geórgia, 1995).
} 
Deus a Caim: "A voz do sangue de teu irmão clama a mim do chão onde está derramado". (Gen. 4:10) ${ }^{20}$

Nesses tempos tão perigosos, Simkins não tinha paciência com o gradualismo liberal. Em 1947, ela escreveu sobre um raro moderado entre os famosos ensaístas de jornal da Carolina do Sul, George A. Buchanan, do Columbia Record. Buchanan queria concordar com o espírito do controverso relatório do presidente do comitê dos direitos civis, mas, ao invés disso, ele criticou a péssima escolha do momento, dizendo que o relatório iria ter efeito negativo, como tantos gestos não moderados em favor dos direitos dos negros. A resposta de Simkins foi curta e direta: "Bem, qualquer hora pode ser a hora errada para as pessoas fracas e sem princípios fazerem o que é certo. A coisa a fazer com os residentes de Bilbolândia ${ }^{21}$ (...) é dar trabalho para eles e deixá-los, em claro desafio, elegerem quem eles bem entenderem”. Buchanan achava que o efeito seria que o lixo branco ${ }^{22}$ do Mississipi se uniria em torno de líderes mais reacionários do que nunca. Mas, disse Simkins, se os eleitores brancos "estão dispostos, por despeito, a sofrer a vergonha e a desgraça que vêm com a representação por palhaços, pretensiosos, tolos e brigões, [então] ‘deixa as águas rolarem'. A hora do cafuné acabou!”. ${ }^{23}$

Todavia, Simkins guardou a maior parte de seu veneno para os "falsos líderes" de sua própria raça. Escrevendo sobre a Associação Estadual dos Professores de Palmetto, que tinha abandonado recentemente seu gradualismo e se filiado à dessegregação escolar, Simkins exultou pelo triunfo de seus aliados sobre a complacência e cumplicidade dos líderes negros costumeiros. Agora liderados por "homens capazes e destemidos", a associação de professores tinha sido "tirada" do "brejo", onde havia "ficado durante anos, devido a manobras diabólicas daqueles que pregavam que 'não estamos prontos ainda, meninos e meninas". Falsos líderes tinham se sentido confortáveis demais, ela

${ }^{20}$ Simkins, MS manuscrito de uma coluna para o Norfolk Journal and Guide, 17 de maio de 1947, Simkins Papers, USC, caixa 2. Simkins também expressa visões pessimistas sobre a natureza humana e relembra sua insatisfação com o gradualismo liberal, nas entrevistas de Jacquelyn Hall no SOHP, transcrito II, p. 89, 5053, 64.

21 "Bilbolândia" é uma referência sarcástica ao Sul segregacionista, simbolizado aqui pelo nome do senador Bilbo, líder da bancada segregacionista no congresso dos Estados Unidos. (N. do T.)

22 "Lixo branco", ou white trash é um termo que se refere aos brancos mais pobres e (presumivelmente, seguindo a lógica do racismo científico do final do século XIX) racialmente degenerados do sul. No imaginário brasileiro, a imagem mais acessível e popular seria a família Busca-Pé. (N. do T.)

${ }^{23}$ Simkins, MS da coluna para 15 de nov. de 1947. Ela rejeitou o gradualismo liberal em sua próxima coluna, para 22 de nov. de 1947. Ambos nos Simkins Papers, USC, caixa 2. 
dizia. "Desde que os 'antilíderes' estivessem bem alimentados e aquecidos, e espertos o suficiente para deixarem as viseiras nos professores nervosos, mal pagos e famintos, eles sabiam que tudo estava 'muito bem, obrigado'". Mas agora a "cortina de fumaça" dos antilíderes se havia dissipado. Agora, a "quinta coluna" tinha sido exposta. Simkins sentia um certo prazer em desmascarar esses traidores: “Expor os 'antilíderes' e os ‘vendidos' não era fácil”, ela dizia, "mas era um esporte bem estimulante e prazeroso". ${ }^{24}$ Em um discurso em 1948 sobre economia, Simkins referiu-se aos habitantes de Carolina como negros, dizendo que "OITENTA ANOS DEPOIS [da emancipação] - no começo da QUARTA GERAÇÃO dos removidos do cativeiro físico -, somos todos cidadãos americanos nascidos livres, do status MAIS MISERÁVEL POSSÍVEL. Mas esse não é o pensamento mais patético", ela disse. "Muitíssimos de nós somos $100 \%$ americanos de alma, muito satisfeitos, satisfeitos de nos movermos adiante como vacas contentes, espantando as moscas e ruminando e seguindo o caminho batido do resto do rebanho." Neste e em outros discursos, Simkins repetia, nas palavras da Bíblia de King James: "A VELHA ORDEM MUDARÁ". Todavia, ela rejeitava a idéia de que a mudança aconteceria automaticamente ou pouco a pouco. "Temos que trabalhar para a mudança, temos de nos alegrar pela mudança e temos de [achar uma forma de] lucrar com a mudança". Ela enfatizava a vigilância:

Temos de manter um OLHO DE ÁGUIA em relação aos maus líderes dentro de nossas fileiras raciais. Há demagogos, egoístas e desonestos em todas as raças. Temos de ESTAR ATENTOS - e sumariamente COLOCAR NO OSTRACISMO aqueles que venderiam sua própria raça para obter ou manter lugares de prestígio, poder e lucro para si próprios. ${ }^{25}$

Por toda a sua retórica de raios e trovões - retirada diretamente dos últimos capítulos do Velho Testamento -, Simkins tinha um pragmatismo maquiavélico sobre o poder. Calejada por anos de prática na organização da Associação de Tuberculose, bem como da NAACP, ela enfatizava a importância da "coalizão e coordenação". Ela não assegurava falsamente uma vitória fácil. A batalha contra a "oposição obstinada" e os "negros colaboracionistas" exigia,

\footnotetext{
${ }^{24}$ Simkins, MS de coluna para 15 de nov. de 1947. Mais sobre o tema "black Quisling" aparece na coluna MSS para 29 de nov. de 1947 e 27 dez. de 1947, nos Simkins Papers, USC, caixa 2. Ver também transcrições II do SOHP, p. 64-67, especificamente sobre os pregadores. Ela se lembra de ser uma "renegada" e pária em muitos momentos das entrevistas - ex. no transcrito I, p. 32-33, 39-40; transcrito II, p. 9, 14, 32, 34, 43, 59-60.

${ }^{25}$ Simkins, notas para pregação, s.d. [cerca de 1948], Simkins Papers, USC, caixa 5.
} 
como ela escreveu no esboço de um discurso, "DEDICAÇÃO TOTAL À CAUSA, NUNCA GANSANDO, SEMPRE LUTANDO PARA ATINGIR O OBJETIVO”. Para vencer, os guerreiros de Deus deveriam não somente mudar a forma como as pessoas pensavam, mas fazer com que as pessoas transformadas votassem: "Conscientizem-se de que os políticos não podem ser mudados", ela explicou a uma platéia. Os negros teriam de adquirir poder pela autodisciplina e sacrifício: "Temos de construir força econômica - segurança-desenvolver a capacidade de poupar". Ela passou grande parte da vida praticando e aperfeiçoando essas táticas. Com King, Rustin e Deus, e sabe-se quantas outras pessoas menos conhecidas, Simkins deixou um legado de pensamento e experiência no qual outros rebeldes se basearam mais tarde. ${ }^{26}$

\section{A contenda dos segregacionistas com sua própria religião}

Por mais surpreendente que possa parecer, os apelos religiosos dos supremacistas brancos não conseguiam chegar perto dos dos líderes dos direitos civis. Os segregacionistas claramente não tinham confiança na base cristã de sua causa, e sua falta de confiança foi a maior surpresa de todas na batalha cultural pelos direitos civis. O temor e a inveja dos liberais pelo tradicional desavergonhado uso conservador da religião, para gerar entusiasmo e solidariedade, não eram justificáveis no caso dos segregacionistas dos anos 1950 e princípio dos anos 1960. Desde os estudos pioneiros de Numan Bartley, Neil McMillen e I. A. Newby nos anos 1960 e começo dos anos 1970, a maioria dos historiadores negligenciou o lado branco da batalha. A difundida suposição de que havia uma guerra espiritual sobre as tradições fundamentais da cultura sulista nos anos 1950 e 1960 não se sustenta diante de análises mais recentes das evidências disponíveis. Muito pelo contrário, o registro de fervor religioso aparece marcadamente invertido para o lado dos negros. Entre os manifestantes negros, as experiências de conversão eram comuns, e os encontros e manifestações dos direitos civis freqüentemente deram lugar a outros aspectos revivalistas. ${ }^{27}$ Os segregacionistas, ao contrário, expressavam pouco entusiasmo por sua

${ }^{26}$ Simkins, rascunho de discurso/pregação, na parte de trás de folhetos de campanha, s.d. [ca.1960], Simkins Papers, USC, caixa 5.

${ }^{27}$ Um capítulo inteiro de $A$ stone of hope é dedicado a esses aspectos revivalistas. Uma versão anterior deste capítulo apareceu como "Religious revivalism in the civil rights movement", African American Review (Winter 2002). 
própria religião e, de fato, evidenciaram frustração e raiva em relação a ela. Esse desequilíbrio deve ter encorajado muitos cristãos sulistas negros em sua convicção de que Deus estava do seu lado. Os segregacionistas não deixaram registro de citações bíblicas confiantes e freqüentes. A notória estória da "maldição de Ham" (Gen. 9) e as leituras racistas da Bíblia nas quais Deus determinava os "limites de habitação" das nações dos homens, em Atos 17, aparecem muito raramente em publicações segregacionistas e em correspondência privada. ${ }^{28}$ Estes e outros exemplos de "prova com o texto" ao estilo segregacionista aparecem mais freqüentemente em afirmações moderadas e liberais que expõem ao ridículo o segregacionismo extremo. A maioria das referências religiosas segregacionistas eram vacilantes e inconsistentes, rodeadas de desculpas, qualificações e confissões de abertura a interpretações contrárias. Os surpreendentemente poucos religiosos famosos que se identificaram fortemente com a causa

${ }^{28}$ Os argumentos, tanto da "Maldição de Ham" quanto de "fronteiras das nações", estão em um curto trecho por E.K. Oldham, no final de um importante periódico segregacionista, The citizens' council, em maio de 1956. Oldham afirmou que os descendentes do filho de Noé, Ham, tinham sido "segregados a uma posição de servidão)". A identificação da "Maldição de Ham" com a escravidão e outras formas de subordinação é anterior à escravidão racial, de acordo com o medievalista Paul Freedman. (Ver Freedman, Images of the medieval peasant [Imagens do camponês medieval], [Palo-Alto, 1999], cap. 4.) Acadêmicos que antecederam a Guerra Civil podem diferir em quão importante eram as referências bíblicas hamídicas e não-hamídicas na propaganda pró-escravidão. O que pode ser mais importante nos meados do século XX é que os mais famosos segregacionistas tentaram evitar a associação de culpa com a escravidão, a secessão e a Guerra Civil, mas quase ninguém fez, como Oldham, referências positivas à escravidão, ou aos argumentos pró-escravidão. Oldham, que admitiu que Deus nunca reconheceria raças negras e brancas quando dividisse os salvos dos não salvos, não desenvolveu suficientemente sua exegese. Isto provavelmente se deveu ao fato de que qualquer conhecedor dos estudos bíblicos sabia que as referências aos descendentes de Ham não tinham nada a ver com as modernas categorias de raça. Mas obviamente, a passagem de Atos 17 foi a base da insistência da tese histórica cristã da monogênese da raça humana; há muito tempo ela era uma favorita dos igualitários, seu ponto principal sendo que Deus criou todos os homens a partir de "um mesmo sangue". Oldham recomendou que seus leitores lessem o discurso de 1956 do Rev. W. A. Criswell, que circulou amplamente em forma de panfleto, "A segregação é anticristã?". Mas se os leitores de Oldham tivessem feito isso, eles teriam descoberto que o próprio Criswell, o pastor segregacionista mais famoso de todos, nunca relacionou os versos da Bíblia a sua defesa da segregação. Para uma análise mais longa da pregação de Criswell, e os esforços tortuosos de uns poucos outros ministros segregacionistas para se defenderem do que eles entenderam como sendo a visão clerical sulista prevalescente - que a segregação é anticristã -, ver David L. Chappell, "Religious ideas of the segregationists" ["Idéias religiosas dos segregacionistas"], Journal of American Studies 32 (1998), p. 237-262. 
segregacionista tenderam a abordar assuntos nos quais os religiosos não tinham autoridade especial ou conhecimento específico - ciência, criação de animais, lei -, e eles raramente discutiam esses assuntos com fervor ou persistência. Os poucos religiosos segregacionistas que argumentavam com fervor tinham a tendência de cair no tipo de paranóia e fanatismo que afugentava respeitáveis líderes religiosos e leigos e, especialmente, os editores de jornais. Os políticos do sul estavam tão ansiosos quanto os políticos de outros lugares para obter vantagem dos excêntricos e paranóicos, mas eles descobriram que a associação pública com essa gente fazia cada vez mais mal do que bem à sua posição política.

De qualquer forma, os segregacionistas sinceros - aqueles que realmente desejavam a supremacia branca ao contrário daqueles que exploravam a histeria racial para destruir candidatos rivais - queriam uma cruzada pública que fosse consistente e eficiente. Os segregacionistas sinceros se sentiram traídos e abandonados por seus pregadores, que, a seus olhos, eram os líderes naturais em questões de moral e de cultura. A vasta maioria dos membros da convenção batista do sul e uma sólida maioria dos presbiterianos do sul (as duas únicas assembléias denominacionais que permaneceram inteiramente sulistas, tendo os metodistas se reunificado em 1939) se pronunciaram a favor da dessegregação, fato que é surpreendente para a maioria das pessoas hoje em dia, até mesmo historiadores. Mas a luta contra a dessegregação forçada começou nos meados dos anos 1950 com os líderes políticos brancos do sul, em quase completa unanimidade contra a decisão da Suprema Corte, e os líderes religiosos brancos, em comparação, manifestando apoio à "obediência" pacífica da nova lei da terra.

Isto não quer dizer que o clérigo branco do sul apoiava ativamente o movimento pelos direitos civis. De nossa perspectiva atual, e provavelmente da deles mesmos, eles estavam defendendo o princípio conservador de respeito à autoridade devidamente constituída - não insistindo em uma revolução social. O resultado da votação na Convenção Batista do Sul sobre dessegregação das escolas públicas foi de cerca de 9 mil a favor e 50 contra, e na Igreja Presbiteriana (do Sul) foi de 239 e 169, respecti- 
vamente. ${ }^{29}$ Naturalmente, houve muita discordância nas congregações, mas surpreendentemente pouca da parte dos pastores. Quanto mais alta a posição nos escalões do aparato denominacional, nos seminários e nos colégios, tanto integracionistas quanto segregacionistas contavam que a personalidade religiosa seria moderada ou completamente integracionista. Pastores segregacionistas eram em geral marginalizados, intelectualmente tímidos e desprovidos de influência, mesmo entre os segregacionistas. Eram "moscas-mortas", se comparados aos pastores e teólogos de antes da Guerra Civil, que usavam a Bíblia e seus púlpitos de forma brilhante e consistente para conferir dignidade à escravidão e expor o que eles consideravam como a desumanidade da "sociedade livre". Os líderes seculares pró-escravidão tendiam a considerar seus pastores como especialmente úteis e provavelmente indispensáveis à causa. Cem anos mais tarde, os clérigos eram bem menos úteis para os defensores da "instituição peculiar" do sul e bem menos honrados e vitais, como grupo, aos olhos dos líderes ideólogos segregacionistas. Nisso, eles diferiam dos advogados segregacionistas e dos juristas que tinham a mesma convicção. Esses conseguiram igualar o brilho, a convicção e a utilidade de seus antepassados da época anterior à Guerra Civil na luta contra os direitos civis, mesmo tendo muito menos recursos constitucionais.

Em geral, os segregacionistas preferiam atacar do que contar com o clérigo branco sulista. $\mathrm{Na}$ verdade, o anticlericalismo parece ser o tema mais comum e apaixonante dos posicionamentos dos segregacionistas sobre a religião. Um segregacionista em Chattanooga denunciou a posição pró-integração assumida pela Igreja Presbiteriana dos Estados Unidos, dizendo:

A parte triste disso é que, da mesma forma que os veredictos da Suprema Corte e suas violações da Constituição fizeram com que tantas pessoas faltassem ao respeito e perdessem a confiança nas cortes, os líderes em

\footnotetext{
${ }^{29}$ Ver Mark Newman, Getting right with God: southern baptists and desegregation, 1945-1995 [Fazendo o certo com Deus: batistas sulistas e a dessegregação] (Tuscaloosa, 2001), p. 24, e Joel Alvis, Religion and race: southern presbyterians, 1946-1983 [Religião e raça: presbiterianos sulistas] (Tuscaloosa, 1994), p. 57; ver também o editorial, "Southern presbyterians stand up" ["Presbiterianos sulistas se levantam"], na publicação da comunidade negra semanal, The Pittsburgh Courier [O Courier de Pittsburgh], 18 de junho, 1956, p. 6.
} 
nossas igrejas estão forçando seus membros a faltar ao respeito e perder a confiança em nossas igrejas e seus líderes". ${ }^{30}$

Um mês depois da decisão do caso Brown, um dos líderes segregacionistas da Carolina do Sul, o congressista William Jennings Bryan Dorn, queixou-se a seus apoiadores sobre a ampla aquiescência dos brancos sulistas em relação à decisão. Ele estava "apavorado ante a tendência de muitos de nossos líderes de igreja, especialmente sua influência junto à juventude”. ${ }^{31} \mathrm{O}$ representante de Mississippi, John Bell Williams, buscou ajuda do chefe da Association of Citizens' Councils [Associação dos Conselhos dos Cidadãos], William J. Simmons, para financiar uma nova editora segregacionista. Williams pediu que Simmons ajudasse a distribuir uma revista entre os membros das

${ }^{30}$ Este segregacionista acrescentou que as igrejas estavam cooperando com os grupos comunistas: "tendo sofrido lavagem cerebral elas mesmas, [elas] procuravam fazer lavagem cerebral em seus membros (...) O resultado eram pessoas infelizes e igrejas divididas". Ela queria tirar os "professors liberais" dos seminários. Mrs. Willard Steele a L. Nelson Bell, 2 de junho, 1958, Bell papers, arquivos Billy Graham Center, Wheaton College, Wheaton, Illinois, f. 47-48. (Bell, diretor associado do Southern Presbyterian Journal, era um líder intelectual dos conservadores sociais e teológicos na igreja presbiteriana sulista. Ele também era o sogro de Billy Graham e uma espécie de mentor para ele. Bell acreditava em segregação voluntária, mas repetidamente declarou em sua correspondência particular e em um fórum público, publicado na revista Life em outubro de 1956, que a segregação forçada não podia ser justificada biblicamente ou constitucionalmente. Graham era bem mais à esquerda de Bell nesse aspecto.) O presidente da ala da direita da Associação de Direitos dos Estados Americanos afirmou que a "complacência" do sul branco era "um resultado do ensino em nossas escolas, universidades, igrejas". Olin Horton para James Byrnes, 6 de julho, 1955, Byrnes Papers, Clemson University, f. 817 (4). Byrnes, o ex-membro da Corte Suprema de Justiça dos Estados Unidos e ex-Secretário de Estado, era o mais respeitado advogado segregacionista no sul, antes da ascensão do Senador Sam Ervin, da Carolina do Norte. As notas do discurso de um segregacionista da Flórida têm as seguintes, de uma lista de perguntas para discussão: "Estão os líderes de nossas igrejas certos? A segregação é realmente e verdadeiramente anticristã?" Sam Peacock, "The Illegal Decision of the Supreme Court”. Discurso para Federação Tampa para o Governo Constitucional, 21 de maio, 1956, nos Byrnes Papers, f. 839 (2) (3). Um membro do Conselho de Cidadãos de Selma, Alabama, escreveu para um líder advogado e estrategista segregacionista, lamentando o silêncio e a indecisão dos líderes sulistas. Ele disse que planejava falar em um encontro do Conselho sobre o assunto: "Nós vamos realmente expor nossos políticos e pastores". Alston Keith para Charles Bloch, 22 de junho, 1956, Bloch Papers, Macon Public Library, Macon, Georgia. Outras cartas segregacionistas anticlericais incluem: Laurine Wade Douglas para Thomas R. Waring, 6 de janeiro, 1955, e 21 de janeiro, 1955, Waring Papers, South Carolina Historical Society, Charleston, caixa 432. Finalmente, o anticlericalismo levou Waring, o editor do News and Courier de Charleston, a bloquear a publicação da coluna de Billy Graham, pois Graham tinha se tornado integracionista demais para o jornal de Waring, provavelmente a segunda voz integracionista mais influente no sul, depois do News-Leader de Richmond, de James J. Kilpatrick. Tudo isso é discutido nos capítulos 6 e 7 de A stone of hope.

${ }^{31}$ Dorn para seus correligionários, incluindo Eugene S. Blease, 22 de junho de 1954, em Dorn Papers, University of South Carolina, Columbia, S.C., caixa 41. 
igrejas locais, em que "poderia fazer muito para compensar a propaganda integracionista que eles estão ouvindo dos púlpitos". ${ }^{32}$ Medford Evans, um professor de escola dominical metodista, iniciou sua "Declaração" segregacionista na revista do Conselho de Cidadãos lembrando a seus leitores que "a Igreja Metodista foi fundada porque John Wesley rejeitou o autoritarismo eclesiástico", que mais uma vez tinha se tornado um perigo. "Um número demasiado grande de membros de nosso clérigo parece servil com relação ao episcopado e arrogantes com relação à laicidade." Esses clérigos arrogantes usavam o princípio da "liberdade do púlpito" para "abafar a crítica". A igreja precisava equilibrar o princípio do púlpito livre com o da "liberdade da congregação". ${ }^{33}$ Uma publicação segregacionista, o Christian layman [Laico cristão], associou "as mulheres brancas da igreja" com os pregadores sulistas. A acusação apareceu em um artigo intitulado "Será que o Sul está sendo traído por seus pastores e as mulheres brancas da Igreja?", que afirmava: "Padres, pastores e mulheres brancas sulistas são inquestionavelmente líderes na luta pela dessegregação sulista". ${ }^{34}$

A literatura segregacionista está cheia de afirmações de ressentimento em relação à autoridade religiosa. O jornalista da Carolina do Sul William D. Workman foi provavelmente o estrategista mais sensato e conhecedor dos segregacionistas, escrevendo que, ante a pressão de todos os lados para dessegregar, que estava vindo "com freqüência quase enauseante dos clérigos, o sulista vive sob tensão em relação a sua religião, com conseqüências para seu

32 "Ao menos", continuou Williams, "daria à congregação uma base para exigir explicações dos pastores 'integracionistas' (...)”. J. B. Williams para W. J. Simmons, 6/14/57, Williams Papers, Mississippi Department of Archives and History, Jackson, caixa RO33-BO19-S210383.

${ }^{33}$ Medford Evans, "A Methodist Declaration of Conscience" ["Uma Declaração Metodista de Consciência"], The Citizen, janeiro de 1963, 1013; a declaração de Evans também foi publicada no Information Bulletin da Mississippi Association of Methodist Ministers and Laymen, cópia na Association of Citizens' Councils of Mississippi Papers, MDAH, caixa 1. Evans pode ter estado certo quanto a Wesley, mas no seu início na América, o Metodismo era bem mais rigoroso em sua disciplina hierárquica.

${ }^{34}$ Christian Layman [Cristão Laico] (out. 1958), ênfase no original, cópia em John Bell Williams Papers, caixa 10395, MDAH. Só consegui achar um exemplar desta publicação. Ela é quase toda devotada à reimpressão de editoriais e discursos segregacionistas. $\mathrm{O}$ artigo citado aqui baseou-se bastante em um artigo anterior de McCall's e criticava Robert Graetz, chamando-o equivocadamente de sulista. Gaetz era um nortista que exercia o cargo de pastor em uma congregação luterana toda de negros em Montgomery. Ver Chapell, Inside Agitators [Dentro dos Agitadores] (Baltimore, Johns Hopkins, 1994). 
humor". ${ }^{35} \mathrm{O}$ órgão do Conselho dos Cidadãos lançou um editorial com o título "Comunas no Púlpito" 36 e um folheto do Conselho culpava pelo conflito racial os "pregadores que recomendam a 'integração' racial". De acordo com essa visão do mundo, tanto os pregadores do norte como aqueles "bem aqui em casa... em quem colocamos nossa confiança", tinham se alistado no exército inimigo. "É um desperdício de tempo estudar as causas para essa repentina mudança de atitude dos pregadores - pelo menos da maioria deles (...) $\mathrm{O}$ 'gentil cavalheiro de Deus' tem se transformado em uma monstruosidade odiosa, sem paralelo, e pará-lo é a tarefa presente." 37

Alguns seguiam a lógica do anticlericalismo a fim de se dissociarem completamente da religião. Roy Harris, o líder político e às vezes representan-

${ }^{35}$ Workman, The Case for the South [O Caso para o Sul] (New York, Devin-Adair, 1960), 109. Workman atacou os nortistas em geral no mesmo parágrafo, mas a citação vem de uma longa discussão do Cristianismo, na qual Workman deixa claro que a religião dos "sulistas" tinha como referência as assembléias denominacionais sulistas, bem como as nortistas. Em outra ocasião, Workman fez objeção a um editorial no South Carolina Methodist Advocate, que tinha tão pouco tato a ponto de afirmar que "Em geral os Protestantes laicos estão atrasados em relação a seus pastores quanto a entenderem a fé Cristã”, em relação a, entre outras coisas, "relações raciais". Workman contestou: "Esses pronunciamentos dogmáticos de nosso clérigo pressupõem uma sapiência e entendimento dos clérigos que nos é negada, a nós, meros laicos (...) Contam-nos, na verdade, que o pobre, que recebe o título de laico, é incapaz de distinguir entre o certo e o errado A NÂO SER QUE seu entendimento coincida com aquele de nossos ministros mentores". Workman lembrou ao editor que tínhamos tido uma Reforma para nos afastar do controle eclesiástico e admitirmos a liberdade de consciência, um aspecto estranho para um metodista enfatizar. Rascunho de carta ao editor do South Carolina Methodist Advocate, em Workman Papers, USC, caixa 15.

36 "Igrejas Sulistas Urgem a Mistura", The Citizen's Council [O Conselho dos Cidadãos], maio 1958, 1: "Reds in the Woodpile [Comunas na Pilha de Lenha]" "E na Reitoria", editoriais no The Citizen's Council, abril 1958; "Pinkos in the Pulpit" [“Comunas no Púlpito"], editorial, The Citizen's Council, dezembro 1956.

${ }^{37}$ O folheto continuava: "É necessário declarar guerra aos Pregadores? Claro que não. Simplesmente aliste-se no exército contra o Comunismo e seus muitos 'Fronts', às vezes disfarçados, e você automaticamente achará os Grandes Pregadores do Seminário no campo do inimigo. Os Pregadores, safra de 1954, diferem pouco do clérigo da moda no tempo de Cristo, quando Ele disse: 'Você é o pai do demônio e o seu desejo é fazer os desejos de teu pai'. Esses filhos do Demônio crucificaram Cristo e hoje estão crucificando os seus seguidores, na cruz da opinião pública". C. C. Smith, de Dumans, Mississipi, "De Que Lado Estão Os Pregadores?", cópia nos Arquivos dos Assuntos do Conselho de Cidadãos, 19541955, MDAH. Estou agradecido ao historiador Randy Sparks por me chamar a atenção para este documento. De forma semelhante, o segregacionista Charles Behnam direcionou sua crítica violenta ao "Profissional Médio 'Cristão' de nossos tempos", acrescentando: "Estes líderes Edomitas têm as instituições da igreja em suas mãos, da mesma forma que os Fariseus Talmudistas tinham o Templo e a igreja judaica sob controle quando nosso Senhor estava tentando salvá-los". "X-Raying the Racial Issue: Is Integration Scriptural?" (Topton, North Carolina, n.d.) [Tirando um Raio-X da Questão Racial: A Integração é das Escrituras?] (Topton, North Carolina, s.d.), cópia em George Wallace Papers, Alabama Departament of Archives and History, Montgomery, RC2 G320. 
te eleito, foi um dos mais hábeis propagandistas do sul. Quando a hierarquia metodista ousou enviar para sua igreja um novo pastor que tinha assinado um documento contra o fechamento de escolas para evitar a integração, Harris se gabou: "Não fui à igreja desde então". ${ }^{38}$ Talvez a declaração anticlerical mais forte tenha vindo em 1955 de um simpatizante do senador da Carolina do Sul, Strom Thurmond:

Agora deve ser evidente para as forças pró-segregação que seu verdadeiro adversário na luta para permitir a preservação da raça branca na América é a assim chamada religião cristã (...) Deveria ser óbvio que a segregação nos Estados Unidos é uma causa perdida, a menos que as forças pró-segregação se organizem além das linhas estaduais, unam seus conhecimentos e recursos, e lancem um assalto frontal contra a religião organizada, contando a todos a verdade sobre eles mesmos e sobre a assim chamada religião cristã.

Este fã queria que Thurmond organizasse todos os líderes dos estados sulistas para expor tal falsidade, sugerindo que ele "notificasse os líderes das várias organizações religiosas que eles serão expostos como [fraudadores] e sua religião como um mito, uma espécie de bruxaria moderna". ${ }^{39}$ Ao contrário de muitos liberais do meio do século, os segregacionistas não demonstravam ter qualquer inveja dos conservadores tradicionais ou do conservadorismo de uma maneira abstrata. Eles guardavam sua inveja para os pregadores negros de sua própria época. "Você tem de admirar um fato sobre Martin Luther King e seu grupo", Roy Harris disse à revista Time em 1961. "Eles estão dispostos a ir para a cadeia por suas crenças."

\section{Conclusão}

O movimento de direitos civis foi um momento extraordinário na história americana, diferente da "resistência" na qual os afro-americanos, como todos os povos oprimidos conhecidos na história, sempre se engajaram. No decorrer do

\footnotetext{
${ }^{38}$ Harris citado em Atlanta Constitution, 3 de fevereiro de 1960.

${ }^{39}$ Robert A. Wade of Hagerstown, Md., para Thurmond, 23 de dezembro de 1955, Strom Thurmond Papers, Clemson University, f. 1956-12. Onde eu usei o termo entre parênteses "fraudes", Wade usou a palavra "fakirs". Seu uso pode ter sido intencional, mais um reflexo de seu desprezo à devoção religiosa. (A palavra, do árabe "pobre", se refere a medicamentos hindus ou muçulmanos; seu uso mais famoso em inglês foi aquele da descrição irônica (zombeteira) de Churchill em relação a Mohandas Gandhi como um "faquir meio-nu".) Parecia seguro supor, no entanto, que Wade realmente quis dizer fakers [enganadores]. Wade notou que "o Cristianismo foi organizado e operava sob a bandeira de um único Deus, o Deus Judeu, a única raça, a raça humana, com justiça, igualdade, liberdade, paz e muito para todos, apesar das leis de Malthus e Darwin”. Thurmond respondeu, embora brevemente e sem se comprometer. A política de Thurmond parece ter sido responder a todos os loucos, exceto os anti-semitas.
} 
último quarto de século, os historiadores do movimento pelos direitos civis, muito atentos à nova história social, vista de baixo e usando toda a argúcia e os recursos da imaginação da escola que valorizava as "armas dos fracos", tentaram apagar a noção de que algo único aconteceu quando o estado nacional (decisão Brown, 1954) ou uma celebridade burguesa, com educação formal (Martin Luther King, 1955, e seguintes) colocaram a luta pela liberdade dos negros nas manchetes. Uma geração de estudantes foi criada e aprendeu muito com o foco historiográfico dos últimos 25 anos em atividades locais, micro, anteriormente não mencionadas. Mas essas raízes estão impedindo nossa visão da floresta. Fannie Lou Hamer, Modjeska Simkins e outros personagens-chave nos movimentos "locais" não se viam como pessoas comuns, e seus vizinhos locais negros não os viam como comuns. Seus adversários brancos certamente os consideravam extraordinários e, embora a percepção do homem branco comum estivesse moldada por mentiras racistas sobre "agitadores externos", tal mentalidade não era completamente falsa. A esperança dos ativistas negros - que, como Vaclav Havel (entre outros) nos lembra, "definitivamente não é a mesma coisa que otimismo" - os diferenciava dos liberais gradualistas e provavelmente os diferenciava das "pollyannas" sonsas e dos pessimistas resignados do seu próprio grupo demográfico. (Otimismo, Havel nos explica em Disturbing the peace [Perturbando a pa:], é o sentimento de que as coisas vão terminar bem, enquanto esperança é a crença de que as coisas farão sentido em última instância, não importando como elas terminem. A diferença entre o otimismo, a crença de que a vida irá melhorar automaticamente, e a esperança, a crença, baseada na experiência, de que o trabalho e o sacrifício podem tornar a vida melhor, embora nem sempre a tornem, é o fio condutor da grande obra de Christophe Lasch, The true and only heaven [O céu verdadeiro e único].) A compulsão profética de testemunhar publicamente as duras verdades, sejam quais foram seus custos, não é simples. Ao contrário, é muitas vezes oriunda de um sentimento iconoclasta, freqüente e simplesmente anti-social. Quem pode negar que foi preciso coragem e determinação incomuns exigir o direito de voto e acesso igual aos bens públicos no sul dos Estados Unidos nos anos 1950? Aqueles que protestavam e os que não protestavam eram familiarizados com a tática de arrastar os pés, quebrar ferramentas e fingir burrice através das quais milhões de afro-americanos tinham se oposto às ordens de seus pretensos senhores. Aquelas táticas, as celebradas armas dos fracos (como o antropólogo americano James Scott as chamou), não foram suficientes - do mesmo jeito que a mera sobrevivência não era suficiente-para os ativistas dos direitos humanos dos anos 1950 e do princípio dos anos 1960. Essas pessoas ousavam tirar as armas dos fortes. Elas moldavam a política das eleições, embora não pudessem votar; faziam guerra, embora soubessem que seria suicídio fazer guerra com armas. Não contentes em se oporem ao desejo de seus inimigos, destruíram a vontade de seus 
inimigos resistirem a elas, por um tempo. É significativo que pelo menos alguns dos ativistas de base locais não tivessem uma teoria de mudança social a partir de baixo. Mrs. Johnie Carr, organizadora do comitê de transporte do Montgomery Bus Boycott [Boicote de Ônibus de Montgomery], parecia estar a favor de uma teoria da história baseada em "grandes homens". Quando questionada por que, quando tudo foi dito e feito, o período de boicote tinha produzido tanta mudança, ela levantou a voz e disse: "Porque Deus nos mandou aquele homem", querendo dizer Martin Luther King. "E até que Ele julgue apropriado nos enviar outro, não iremos adiante." ${ }^{\prime 0}$ Ouvir com atenção essas vozes do movimento de direitos civis é suspeitar que somente uma crença em forças sobrenaturais - isto é, uma falta de fé na massa da humanidade - pode explicar aquele período extraordinário da luta. Mrs. Carr e outros integrantes do movimento admitiram a existência de seres humanos extraordinários, nos quais uma chama divina se acende em raras ocasiões. Esta perspectiva sugere que as pessoas que reagiram à opressão com atos heróicos de sacrifício provavelmente não se vissem como pessoas comuns, e isso pode também ajudar a explicar um movimento social que se rebelou tanto contra o que os acadêmicos chamam de "afro-cristianismo" da vida diária, quanto contra o estado, o sistema econômico e a ideologia racista branca popular. Tal fato ajuda a explicar por que os liberais conseguiram, por pouco tempo, ter alguma força contra as instituições racistas, as grandes barreiras que a sociedade americana construiu no caminho para a liberdade e a igualdade. Os liberais não fizeram isso sozinhos muitos deles reconheciam que eles não poderiam ter feito. Ao contrário, eles foram varridos para dentro do movimento de direitos civis pelos ativistas que não tinham as barreiras erguidas pela fé liberal no homem. Estes ativistas foram capazes de "suprimir", para usar um verbo bíblico, a resistência de uma maioria branca, que maciçamente disse aos peritos em sondagem de opinião pública que eles apoiavam a segregação e que maciçamente votaram pela segregação quando tiveram oportunidade. Eram maioria numérica, gastavam mais e eram mais bem armados do que aqueles que acreditavam nos direitos civis, mas lhes faltava a inspiração para o sacrifício pelo que acreditavam, bem como a solidariedade.

A determinação e a fé das forças mais fracas foram importantes no movimento de direitos civis, como o foi na Guerra do Vietnã ou em outras instâncias em que grandes nações perderam pequenas guerras. Em uma era em que as ideologias seculares e as revoluções violentas não mais inspiram esperança, o exemplo da conquista daqueles que protestavam pelos direitos civis pode ter muito a nos ensinar. Análises longas e críticas ao século passado - estou pensando no Black book of communism [Livro negro do comunismo], de Stephan Courtois (et al.), e Problem from hell [Problema do inferno], de Samantha Power - nos avisam do perigo de pensar de

${ }^{40}$ Mrs. Johnnie Carr, entrevista com a autora, Montgomery, Alabama, 14 de julho de 1989. 
forma utópica. Courtois e seus colegas enfatizam as conseqüências de assassinatos em grande escala decorrentes de movimentos de massa que acreditam ser possível construir uma sociedade perfeita, livre de conflitos. Power enfatiza o outro lado desta moeda: a falta de vontade de grande número de americanos decentes e de bom coração (provavelmente a cultura mais liberal que já existiu) para crer que o assassinato em massa esteja verdadeiramente ocorrendo. (Seus exemplos mais perturbadores se concentram na falta de vontade em acreditar que uma situação muito ruim, como o Camboja sob Lon Nol, possa piorar muito.) Os ativistas pensantes do movimento de direitos civis - e, talvez, muitas pessoas da base desse movimento, cujos pensamentos não estejam registrados - podem adicionar algo a esses insights sensatos. Os pensadores proféticos descritos anteriormente nos mostram que, se encararmos teorias do futuro da humanidade com grande ceticismo, é possível não somente evitar holocaustos catastróficos, mas também nutrir esperança suficiente para evitar desilusão e desespero. ${ }^{41}$ Uma esperança fundada em um ceticismo tão grande, apesar de ser pequena e dura, pode ser suficiente não somente para dar coragem às pessoas, denunciar ou aliviar o genocídio, mas até mesmo aproximar seu próprio sistema político e econômico aos ideais de liberdade e igualdade. Essa esperança conseguida a duras penas provavelmente

${ }^{41}$ Minha ênfase no ceticismo sobre a humanidade, ao invés de em outros aspectos da "religião", sugere que outro exame longo e minucioso do último século desagradável, o geralmente brilhante Age of Extremes, de E. J. Hobsbawm, erra em sua análise. Hobsbawm mantém que "as religiões tradicionais" não dão "qualquer alternativa plausível" para as "ideologias programáticas nascidas da Idade da Revolução e do século XIX" - cujo erro colossal Hobsbawm agora admite. Tal ênfase, e em A stone of hope, é no ceticismo em relação ao futuro da humanidade. Esse ceticismo é, acredito, a grande lição que as religiões proféticas oferecem ao homem moderno, político. (Às vezes chamadas abraâmicas, estas religiões incluem o Islã e o Cristianismo, bem como o Judaísmo original. O ceticismo, espero que esteja óbvio, se aplica, acima de tudo, a esforços no nome de quaisquer dessas religiões para criar (uma) utopia, ou para controlar a política e a guerra; tais esforços sempre parecem ao ouvido verdadeiramente profético, acho, uma blasfêmia. Minha ênfase não tem sido em quaisquer pressuposições do outro mundo sobre vida-depois-da-morte ou vida depois do fim da história - o que Martin Luther King chamou de "esperança escatológica", que era diferente de sua "pedra de esperança" sobre a vida nesta terra no futuro vislumbrável. Não que o ceticismo possa ser facilmente extraído de crenças sobrenaturais. Creio (não pelas razões psicológicas comumente condescendentes) que as esperanças para outro mundo estão entrelaçadas, na verdade, com o ceticismo profético sobre a humanidade: o esforço quixotesco de John Dewey para separar o que ele gostava na religião do que ele não gostava me parece algo meio bobo e inútil. Não passa de uma forma mais precisa do tipo de Cristianismo original, liberal, não ortodoxo. Por outro lado, os ensinamentos firmemente ateístas de Albert Camus - que inspiraram o estudante ativista de direitos civis Bob Moses, que eu discuto em A stone of hope - sugerem que é possível chegar a um ceticismo profético sobre o homem sem fé no sobrenatural. Reinhold Niebuhr disse que muitos ateístas, em sua experiência, seguiram o exemplo de Jesus mais prontamente e de maneira mais plena do que a maioria dos cristãos. Karl Barth sugeriu algo semelhante em seus discursos bombásticos, desdenhosos e ressonantemente proféticos sobre a corrupção do Cristianismo de fato existente. 
não resolverá a tensão entre aqueles dois ideais exigentes, mas talvez possa dar paciência e humildade em esforços para ajudarem um ou outro. Talvez ela possa impregnar ambos os ideais com realismos e assim ajudar a manter ambos vivos. 